УДК 61: 614.23:614.88-083.98

\title{
ОРГАНІЗАЦІЯ ТА ВДОСКОНАЛЕННЯ НАВЧАЛЬНОГО ПРОЦЕСУ НА КАФЕДРІ ЦИВІЛЬНОГО ЗАХИСТУ ТА МЕДИЦИНИ КАТАСТРОФ СИСТЕМИ ПІСЛЯДИПЛОМНОЇ МЕДИЧНОЇ ОСВІТИ
}

\author{
І. В. Кочін, О. М. Акулова, О. О. Гайволя, Д. О. Трошин, І. Ф. Шило \\ Запорізька медична академія післядипломної освіти
}

\section{ORGANIZATION AND IMPROVEMENT OF EDUCATIONAL PROCESS ON DEPARTMENT OF CIVIL DEFENCE AND MEDICINE OF DISASTERS OF POST-GRADUATE MEDICAL EDUCATION SYSTEM}

\author{
I. V. Kochin, O. M. Akulova, O. O. Hayvolya, D. O. Troshyn, I. F. Shylo \\ Zaporizhian Medical Academy of Post-Graduate Education
}

\begin{abstract}
У роботі проаналізовано багаторічний досвід кафедри цивільного захисту та медицини катастроф Запорізької медичної академії післядипломної освіти 3 підготовки лікарів Державної служби медицини катастроф України.

Long-term experience of department of civil defence and medicine of disasters of Zaporizhian Medical Academy of Post-Graduate Education has been analysed on training of doctors of the Government disaster medicine service of Ukraine in the article.
\end{abstract}

Вступ. Останні десятиріччя у світі відзначені тенденції динамічного зростання вимог до якості освітянської праці. Це пов'язано, перш за все, з величезним попитом в усіх галузях людської діяльності на компетентних фахівців, без яких неможливо розв'язання істотних проблем сучасності [1]. Освіта покликана найбільш повно задовольняти ці потреби суспільства. Це завдання повною мірою стосується й післядипломної медичної освіти. Зростаюча кількість природних, техногенних та соціально-політичних катастроф ставить перед галуззю охорони здоров'я складні завдання та спонукає викладачів кафедр цивільного захисту та медицини катастроф вищих медичних закладів України запроваджувати у навчальний процес більш ефективні методи викладання [2].

Основна частина. 3 використанням теорії систем, процесного та програмно-цільового підходу досліджено та узагальнено багаторічний досвід роботи професорсько-викладацького складу кафедри цивільного захисту та медицини катастроф (КЦЗМК) Запорізької медичної академії післядипломної освіти (ЗМАПО) щодо підготовки лікарів з дисципліни "Медицина катастроф", визначені основні напрямки вдосконалення навчального процесу.

Змістовною та регламентуючою основою організації навчального процесу, розробки навчальних та тематичних планів на кафедрі для півторамісячних (234 години) та одномісячних (156 годин) циклів тематич- ного удосконалення (ТУ) є Уніфікована програма післядипломного навчання лікарів 3 організації медичного забезпечення населення у надзвичайних ситуаціях (НС), у яку з перебігом часу та нових вимог постійно вносяться зміни та доповнення, що узгоджуються на кафедральних методичних нарадах. Професорсько-викладацький колектив КЦЗМК проводить заняття на таких циклах ТУ: “Планування та організація медичного забезпечення населення у НC”; “Організація розгортання і роботи лікарень у HC”; “Організація медичного забезпечення населення у НC”; “'Організація роботи швидкої медичної допомоги у НС”; “"Планування та організація екстреної медичної допомоги (ЕМД) постраждалим в умовах техногенних та природник катастроф". За період 2005 - 2010 рр. проведено 42 цикли ТУ, на яких навчалось 1428 лікарів-слухачів. Згідно з заявками керівництва Запорізького територіального центру екстреної медичної допомоги та медицини катастроф (ЗТЦЕМД та МК) за період 2005 - 2010 pp. було проведено 17 циклів ТУ з навчанням 578 лікарів Запорізької області. Наступним завданням КЦЗМК $є$ підготовка лікарівслухачів з питань організації екстреної медичної допомоги та медицини катастроф (ЕМД та МК) циклів ТУ та передатестаційних циклів суміжних кафедр ЗМАПО факультетів: терапевтичного, хірургічного та сімейної медицини, а також керівників закладів галузі охорони здоров'я за 7-годинною програмою,

\footnotetext{
(c) І. В. Кочін, О. М. Акулова, О. О. Гайволя та ін.
} 
яка відрізняється за тематикою занять для кожного з чотирьох вищеозначених контингентів. За цією програмою на КЦЗМК пройшли навчання 1035 груп загальною кількістю 26227 лікарів-слухачів з суміжних кафедр 3МАПО, в тому числі: 526 груп (12 617 лікарів-слухачів) хірургічного факультету, 345 груп (9318 лікарів-слухачів) терапевтичного факультету та 164 групи (4292 лікарів-слухачів) факультету сімейної медицини.

Підготовка лікарів-інтернів клінічних кафедр ЗМАПО здійснюється за 7- та 14-годинними програмами п'яти видів, розроблених кафедрою з врахуванням як особливостей предмета викладання для лікарів-інтернів різних кафедр терапевтичного та хірургічного факультетів, факультету сімейної медицини, так із врахуванням підвищення вимог до освіти лікарів-інтернів з боку МОЗ України, Управління охорони здоров' я Запорізької обласної державної адміністрації (ОДА), відділу інтернатури ЗМАПО. Для підвищення якості підготовки лікарів-інтернів з питань організації надання ЕМД населенню при НС розроблені та затверджені на Раді терапевтичного факультету ЗМАПО навчальні та тематичні плани для п'яти категорій лікарів-інтернів, зокрема: лікарів-інтернів терапевтичного профілю (14 годин); лікарів-інтернів факультету сімейної медицини (14 годин); лікарівінтернів хірургічного профілю (14 годин); інтернівстоматологів (7 годин); лікарів-інтернів лабораторної діагностики (7 годин). Всього за 2005 - 2010 pp. на кафедрі навчались 575 лікарів-інтернів у 84 групах.

Зростання загрози тероризму для глобальної та національної безпеки вимагає організації та проведення цілеспрямованої підготовки лікарів України з цієї актуальної проблеми сучасності. 3 цією метою професорсько-викладацьким складом кафедри підготовлена навчально-методична документація нового циклу ТУ, надруковано навчальний посібник, який затверджено Міністерством освіти та науки України [3], інформаційний лист щодо ліквідації медико-санітарних наслідків можливих терористичних актів [4].

Враховуючи означені дані, педагогічне навантаження викладачів КЦЗМК в середньому за рік склало 4628 годин, при запланованому 4376 годин, що становить 105,8 \%. На всі лекційні, практичні та семінарські заняття розроблені методичні розробки, які періодично переглядаються, доповнюються новою літературою. Створено електронний каталог рекомендованої до самостійного вивчення лікарями-слухачами літератури. У переліку навчально-методичної літератури започатковано розділ “Правові, дирек- тивні та нормативні акти організації роботи та функціонування Державної служби медицини катастроф (ДСМК) України”. Кафедрою обрано напрям на розширення регіонів України для проведення виїзних циклів ТУ. Крім Запорізької області, проводиться підготовка лікарів у Дніпропетровській, Донецькій, Херсонській, Кіровоградській, Миколаївській та інших областях, що є запорукою покращення діяльності ТЦ ЕМД та МК та підвищення кваліфікації медичних працівників цих регіонів з питань організації та надання ЕМД при НС.

3 метою підвищення викладацької майстерності, запозичення досвіду, узгодження навчального матеріалу викладачами кафедри практикуються взаємні відвідування занять 3 наступним їх обговоренням на методичних нарадах кафедри. Для оптимізації навчального процесу на КЦЗМК використовується комплексний підхід з поєднанням традиційних форм навчання й сучасних навчально-інформаційних технологій, спрямованих на підвищення якості підготовки лікарів. На всі види аудиторних занять підготовлено ілюстративний матеріал: таблиці, мультимедійна презентація, навчальні фільми. Кафедра має відеотеку з 28 навчальних фільмів 3 тематики природних, техногенних та соціально-політичних катастроф. Перегляд навчальних фільмів завершується проведенням інтерактивних семінарів з аналізом переглянутого матеріалу та висновками щодо оптимізації організації та надання ЕМД при НС. Ми вважаємо таку форму організації навчання важливою для максимально ефективного засвоєння теоретичного матеріалу, опрацювання практичних навичок та стимулювання інтересу лікарів до дисциплін цивільного захисту та медицини катастроф.

Аналіз результатів реформи медичної освіти в Україні свідчить про необхідність негайного вирішення низки щільно пов'язаних методичних проблем, серед яких важливим елементом $є$ контроль знань лікарів-слухачів та інтернів [5]. Контроль знань на КЦЗМК організовано та проводиться на принципах: різноманітності (іспити та заліки, опитування усне або письмове, реферати, семінари, тести), систематичності (попередній, поточний, рубіжний, підсумковий, заключний), усебічності (контроль охоплює основні розділи навчальної програми і нараховує більш ніж 500 питань), диференційованості (враховує особливості слухачів кожного фаху), об'єктивності. Якісна організація, керування та корегування навчального процесу відповідно до результатів контролю знань, професійне та адекватне поєднання усіх його елементів сприяє підвищенню якості навчального про- 
цесу і як наслідок - якості підготовки лікарів-слухачів та інтернів.

Враховуючи нестачу навчально-методичної літературиз предметної галузі цивільного захисту населення та медицини катастроф, авторським колективом КЦЗМК за 2005 - 2010 рр. було підготовлено та надруковано для фахової підготовки медичних працівників ДСМК України, лікарів-слухачів циклів ТУ, лікарів-інтернів та населення 10 навчальних посібників. За 1981 - 2010 рр. було підготовлено та видано 41 підручник та навчальний посібник [6, 7]. Спільно з Запорізькою обласною санітарно-епідеміологічною станцією розробляється навчальний посібник “Основи діяльності Державної санітарно-епідеміологічної служби України в мережі спостереження та лабораторного контролю при НС".

Важливою ланкою навчального процесу є науково-дослідна робота (НДР) кафедри. Враховуючи специфіку та потребу Придніпровсько-Донецького регіону інтенсивної промислової діяльності, КЦЗМК протягом останніх років плідно працює з розв'язання проблем організації та оптимізації надання ЕМД населенню та працівникам хімічно небезпечних об’єктів при НС. За матеріалами і результатами кафедральної НДР у 2004 - 2006 рр. було надруковано 59 наукових праць, в тому числі 10 публікацій, що відповідають вимогам ВАК України; у 2007-2011рр. - відповідно 61 та 29 наукових праць. Матеріали та результати НДР широко використовуються у навчальному процесі.

За період 2005 - 2010 рр. викладачі кафедри зробили 148 доповідей на Всеукраїнських, обласних і міських науково-практичних конференціях, засіданнях Навчально-методичного центру та науково-методичної ради з питань цивільного захисту та безпеки життєдіяльності Запорізької області.

Ефективна підготовка кадрів 3 питань організації ЕМД та МК неможлива без спільної роботи з орга-

\section{Лiтература}

1. Поняття “компетентності” та “компетенції” у підготовці фахівців Державної служби медицини катастроф / І. В. Кочін, Д. В. Ількаєв, О. М. Акулова [та ін.] // Запорожский медицинский журнал.- 2008.--№ 4.- С. 150-152.

2. Підготовка формувань та закладів Державної служби медицини катастроф до роботи у надзвичайних ситуаціях : навчальний посібник / [I. В. Кочін, Г. О. Черняков, Н. В. Баранова та ін.]; під ред. д-ра мед. наук, академіка І. В. Кочіна. - Запоріжжя : ЗДІУЛ, 2000. - 128 с.

3. Кочін І. В. Діяльність Державної служби медицини катастроф України з протидії біологічному, хімічному та ядер- нами управління та закладами охорони здоров'я Запорізької ОДА, ЗТЦ ЕМД та МК, Управлінням з питань НС Запорізької ОДА, Навчально-методичним центром цивільного захисту та безпеки життєдіяльності Запорізької області. Професорсько-викладацьким складом кафедри надаються консультації керівникам і фахівцям Управління охорони здоров'я Запорізької ОДА, Управління з питань НС та цивільного захисту населення Запорізької міської Ради, головному спеціалісту з питань радіаційного та хімічного захисту відділу захисту населення і територій, начальникам штабів з ліквідації наслідків НС 3 питань організації ЕМД, діяльності ДСМК, їі взаємодії з іншими аварійно-рятувальними службами, організації та проведення комплексних навчань медичних формувань щодо ліквідації медико-санітарних наслідків НС. Триває співробітництво з Управлінням $з$ питань НС Запорізької ОДА та Запорізьким державним воєнізованим спеціалізованим аварійно-рятувальним підприємством “Кобра”, для яких розроблено програму 3 медичної підготовки аварійно-рятувальних підрозділів, проводяться заняття та приймаються іспити.

Співпраця 3 керівниками органів Управління та закладів охорони здоров'я вказує на велику потребу практичної медицини у поглибленні знань лікарів 3 питань цивільного захисту населення, організації діяльності ДСМК України та надання ЕМД при НС, проведенні циклів ТУ у лікувально-профілактичних та санітарно-профілактичних закладах $[8,9]$.

Висновок. Таким чином, аналіз організації навчального процесу на КЦЗМК ЗМАПО свідчить про необхідність організації, здійснення та вдосконалення навчального процесу на кафедрах цивільного захисту та медицини катастроф вищих медичних закладів України згідно з завданнями, які поставлені державою, та потребами ДСМК у підготовці високопрофесійних медичних кадрів з питань організації та надання ЕМД при НС.

ному тероризму : навчальний посібник / I. В. Кочін, О. М. Акулова. - Запоріжжя : ЗДМУ, 2010. - 128 с.

4. Алгоритм ідентифікації біологічного терористичного акту : інформ. лист / І. В. Кочін, О. М. Акулова, І. Ф. Шило [та ін.] // Укрмедпатентінформ МОЗ України. - 2009. - № 209. $-4 \mathrm{c}$.

5. Освіта фахівців охорони здоров'я як елемент системи управління Державною службою медицини катастроф України територіального рівня / О. О. Гайволя, І. В. Кочін, О. М. Акулова [та ін.] // Запорожский медицинский журнал. -2010. - № 2. - С. 164-167. 
6. Інформаційно-методичне забезпечення підготовки кадрів служби медицини катастроф / I. В. Кочін, Г. О. Черняков, Н. В. Баранова [та ін.] // Запорожский медицинский журнал. -2001. - №2.-С. 67-69.

7. Кочін I. В. Узагальнення досвіду забезпечення методичною літературою навчального процесу з підготовки фахівців Державної служби медицини катастроф України / І. В. Кочін, Г. О. Черняков, Н. В. Баранова // Проблеми медичної науки та освіти. - 2001. - № 4. - С. 16-20.

8. Охорона праці та безпека життєдіяльності населення при надзвичайних ситуаціях : навчальний посібник / [І. В. Кочін, Г. О. Черняков, П. І. Сидоренко та ін.]; за ред. проф. І. В. Кочіна. - К. : Здоров’я, 2005. -432 с.

9. Кочін І. В. Медицина катастроф : виробниче видання / І. В. Кочін, Г. О. Черняков, П. І. Сидоренко; за ред. проф. І. В. Кочіна. -К. : Здоров’я, 2008. - 724 с. 